\title{
Recreation suitability analysis: application in protected and non-protected areas
}

\author{
I. de Aranzabal ${ }^{1}$, M. F. Schmitz ${ }^{1}$, P. Aguilera $^{2}$ \& F. D. Pineda ${ }^{1}$ \\ ${ }^{I}$ Department of Ecology, University Complutense of Madrid, Spain \\ ${ }^{2}$ Department of Vegetal Biology and Ecology, \\ University of Almeria, Spain
}

\begin{abstract}
The influence of tourism in some territories should constitute a priority objective in environmental planning and management. Indeed, this activity tends to occur in areas that are clearly fragile in the socio-ecological sense. Sensible development of tourism involves the correct use of natural resources in protected areas and in many non-protected areas containing particularly sensitive natural and cultural values. Methodological approaches for recreational planning should include an appraisal of the natural, visual and cultural values of the landscape, visitors' preferences and demands, and an analysis of the relationship between landscape supply and demand.

In this paper we apply a model that relates natural values and visitor preferences for suitable management of both protected and non-protected natural areas in the surrounding territories. To this end: i) we characterised the natural and cultural landscapes of eastern Andalucía (Spain), considering characteristics of the territory that are potentially attractive for tourism and ii) we typified the visitors. We analysed the demand for tourism by means of questionnaires filled in by the visitors and which contained aspects relating to their preferences according to the features of the landscape. Thus, we obtained different types of visitors with different attitudes and perceptions in relation to the territory. The model used enabled us to establish the spatial correspondence between the different zones of the territory and demand according to visitors' preferences.

The procedure employed allowed for the design of maps at different scales showing the distribution of preferences and the possible areas to be visited by the different types of tourists and the degree of satisfaction these obtain. This provides a useful reference for the design of a rational management system for tourism in the territory, inside and outside protected natural areas.

Keywords: inside-outside protected areas analysis, socio-ecological systems, cultural landscapes, visitor perceptions, cross-boundary management, naturebased tourism, visitor-landscape interaction model, nature reserve network.
\end{abstract}




\section{Introduction}

Protected areas are the principal components of most conservation approaches. Their value depends on many important factors, among which we can highlight their role in environmental education, in the conservation and use of natural and cultural resources, in tourism and public enjoyment and in the socioeconomic development of local communities (Götmark and Nillson [1], Walpole and Goodwin [2], Gaston et al. [3], Kalamandeen and Gillson [4]).

Over the last few decades the significance of nature reserves as educational and recreational areas has increased constantly and nature-based tourism is the principal means of ensuring the selffinancing of protected areas (Dharmaratne et al. [5], Li et al. [6], Moore and Polley [7]). Thus, demand for tourism and leisure should be included among the criteria used for the selection, zoning, planning and management of these zones (Gül et al. [8], Roman et al. [9]).

As nature reserves do not exist in isolation, regional planning and management needs to consider an area that not only embraces the limits of the protected areas, but also a larger ecological and culture-related landscape (Schonewald-Cox et al. [10], Gulinck et al. [11]). Likewise, correct recreational planning calls for the development and application of practical methods for identifying the characteristics of the protected areas and those of the landscape matrix in which the protected sites are included (Gaston et al. [3]). Moreover, there is a need to consider the spatial relations of these sites within the network. This connectivity is affected by the dynamics of the land outside the boundaries of the protected areas, which are critical to the maintenance of ecosystem processes (Margules and Pressy [12], Tischendorf and Fahrig [13], Cerdeira et al. [14], Rothley [15], Pineda et al. [16]).

In this context, sustainable recreational planning requires a detailed analysis comparing visitor supply (landscape values and features) and demand, both inside and outside protected areas, in order to take coherent management decisions (Bell [17], Roovers et al. [18], Gül et al. [8], Schmitz et al. [19-21]). In this paper we apply a visitorlandscape interaction model for the suitable management of a nature reserve network and the surrounding landscape. This quantitative method can assist the landscape zoning process and provides a practical tool for recreational planning and landscape conservation and management.

\section{Study area}

We studied a protected area network in eastern Andalucía (Spain) and adjacent territories (Fig. 1). The area, ca $25,563 \mathrm{~km}^{2}$, comprises a series of twelve protected sites located in a landscape matrix with a high degree of spatial heterogenenity and notable climatic, lithological and geomorphological contrasts. The landscape presents a noteworthy cultural component, the traditional agro-silvo-pastoral features of the Mediterranean basin predominating. 


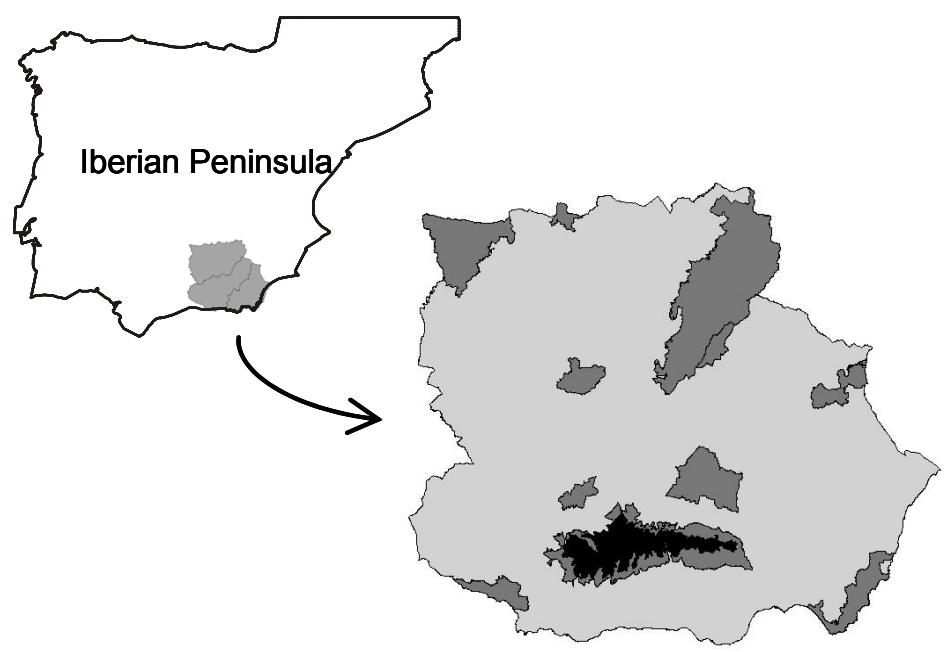

Figure 1: Protected area network in the study area (eastern Andalucía, Spain).

\section{Supply of landscape recreational resources}

The landscape characterization for nature-based tourism was based on the inventory and spatial identification of recreational resources (Table 1). The landscape features selected were the ecological, aesthetic and cultural assets recognised as being particularly attractive for tourism. We used as a spatial reference a grid system made up of $2 \mathrm{~km} \times 2 \mathrm{~km}$ cells. Thus, we obtained a data matrix of 9,015 cells $\times 31$ landscape tourist features. The values of this matrix represent the spatial occupation (in percentages) of each landscape feature in each cell.

\section{Visitor preferences}

In order to identify the visitors' preferences, we conducted 800 surveys at sampling points selected throughout the study area due to their potential value for leisure and tourism. Therein, the people interviewed were selected at random. These data were collected over one year.

The surveys were based upon a series of questions related to aspects of the landscape tourist features (Table 1). We used a structured and standardized questionnaire, previously tested in other areas, and adapted to the characteristics of the study area (Schmitz et al. [19-21]).

With the data collected we constructed a matrix of 800 observations (people interviewed) $\times 31$ variables (answers by the visitors to the questions about landscape features), the values of which represent the frequency of answers to the questions asked. This matrix enables us to quantify the preferences of the visitors for the landscape tourist features. 
Table 1: Natural and cultural tourist features considered in the landscape characterization and in the surveys of the visitors' landscape preferences.

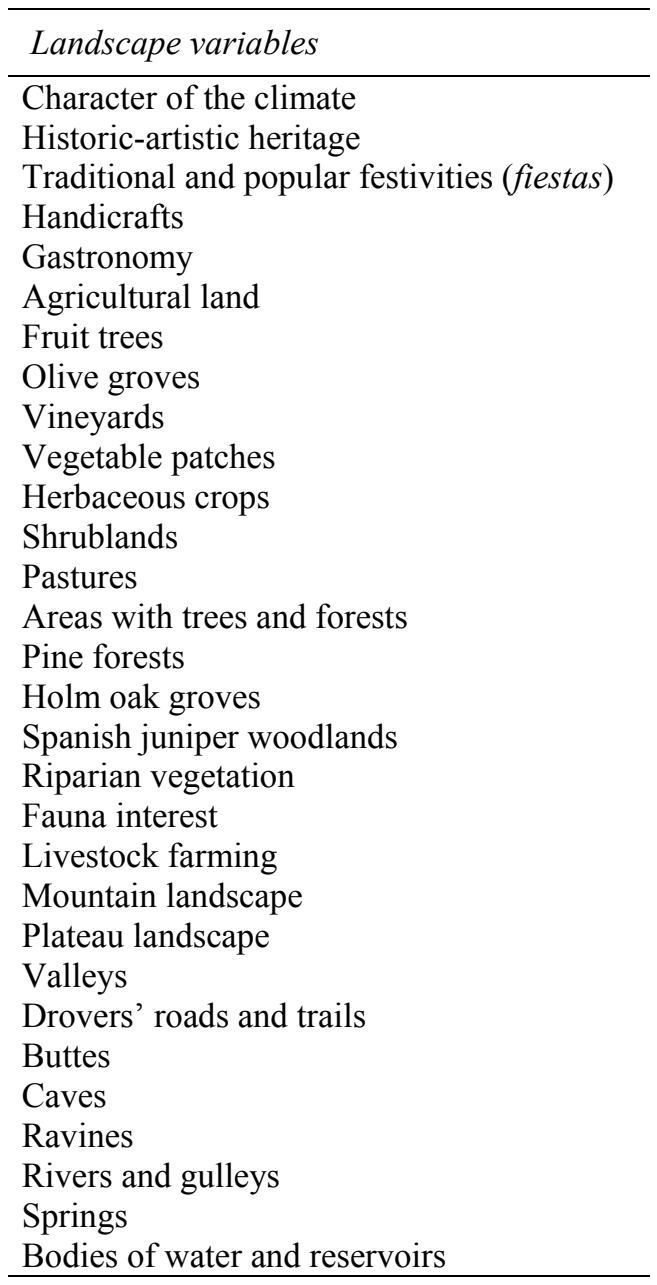

\section{Landscape zoning: a spatial model of visitor behaviour}

We conducted landscape zoning based on visitor landscape perception and preferences, applying a quantitative integrated method process based on a multiplication of matrices (Schmitz et al. [19, 20]). From the two matrices designed (spatial matrix of landscape recreational resources and visitor preferences matrix) we obtained a product matrix the elements of which quantified the spatial interaction between the tourist preferences and the landscape tourist features. 
The landscape zoning process produced a series of spatial units that depend upon the different degrees of fit considered in the relationship between landscape supply and visitor preferences. The result is a map showing is the suitability of each area for nature-based tourism. Figure 2 shows a landscape zoning with five sectors or fit levels (very low, low, medium, high and very high).

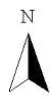

Figure 2:

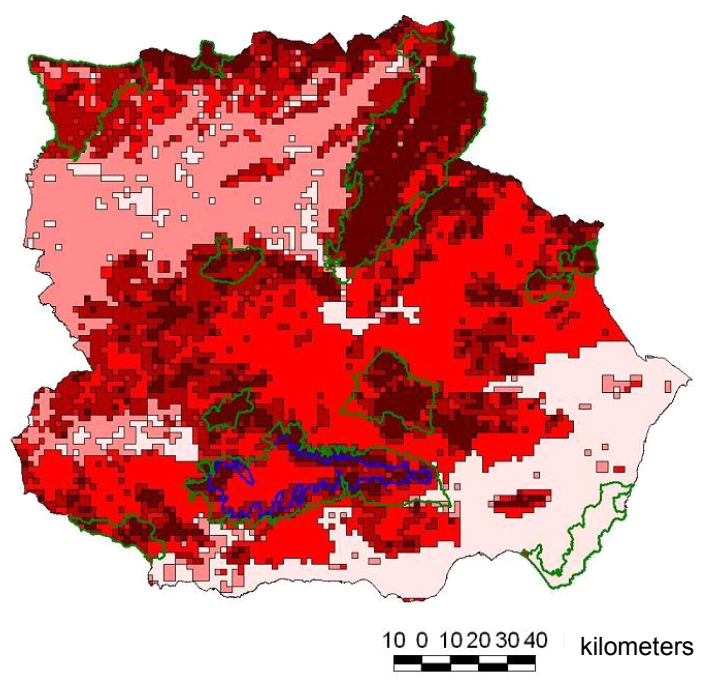

Fit levels

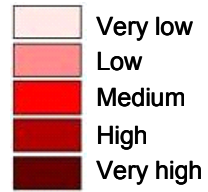

The land units obtained also enable us to characterise the visitors' spatial outdoor recreational niche, which is represented by the areas in which fit models are obtained with high and very high values. Very low values for the interaction between landscape features and landscape preferences correspond to areas that do not present the necessary conditions to satisfy the expectations of the naturebased tourists.

The spatial model was applied to the whole territory, without considering the protected area network. The spatial identification of the protected sites shows that these are located in sectors with different degrees of fit and that the characteristics of the non-protected adjacent areas are similar to those of the areas within the boundaries of the protected areas (Fig. 2). In practice, however, the boundaries established involve the application of different management policies inside and outside nature reserves, a fact that might interfere with current landscape connectivity. There is an evident need for cross-boundary management of the landscape.

\section{Final remarks}

Public enjoyment and tourism are driving forces which are generally considered as an opportunity to promote the socioeconomic development of a territory, but 
which also constitute an important reference both for landscape planning and management and for landscape conservation and monitoring of environmental quality (Lacitignola et al. [22], Petrosillo et al. [23]).

In this study we made use of an integrated approach that considers the landscape's supply of recreational resources and visitors' demands and preferences, and the relationship between these as a basis for the sustainable management of tourist areas (Daily [24], Bell [17], Roovers et al. [18], Gül et al. [8], Schmitz et al. [19-21], Moore and Polley [7]). This quantitative method can assist the landscape zoning process and enables the potential spatial behaviour of visitors to be estimated and their outdoor recreational niche to be characterised.

The results obtained highlight differences among visitors, planners and policy-makers with regard to landscape appraisal. Although protected areas are one of the prominent conservation tactics (Soulé [25]), in many cases their boundaries do not coincide with the landscape as perceived by people (Martin et al. [26], Farrell et al. [27], Dasdemir [28], Buisson and Dutoit [29], Schmitz et al. [20] Cihar and Stankova [30], Nebbia and Zalba [31]). Protected areas can be considered as nature conservation nuclei in a landscape continuum the future of which depends both upon the maintenance of their characteristics and of those of the surrounding landscape. This highlights the importance of cross-boundary management and of the development and application of suitable techniques for informed decision-takers (Schonewald-Cox et al. [10], Steiner et al. [32]).

\section{References}

[1] Götmark, F. \& Nillson, C., Criteria used for protection of natural areas in Sweden 1909-1986. Conservation Biology, 6, pp. 220-231, 1992.

[2] Walpole, M.J. \& Goodwin, H.J., Local attitudes towards conservation and tourism around Komodo National Park, Indonesia. Environmental Conservation, 28, pp. 160-166, 2001.

[3] Gaston, K.J., Charman, K., Jackson, S.F., Armsworth, P.R., Bonn, A., Briers, A., Callaghan, C.S.Q., Catchpole, R., Hopkins, J., Kunin, W.E., Latham, J., Opdam, P., Stoneman, R., Stroud, D.A. \& Tratt, R., The ecological effectiveness of protected areas: The United Kingdom. Biological Conservation, 132, pp. 76-87, 2006.

[4] Kalamandeen, M. \& Gillson, L., Demything "wilderness": implications for protected area designation and management. Biodiversity and Conservation, 16, pp. 165-182, 2007.

[5] Dharmaratne, G.S., Yee Sang, F. \& Walling, J., Tourism potentials for financing protected areas. Annals of Tourism Research, 27, pp. 590-610, 2000.

[6] Li, W., Ge, X. \& Liu, C., Hiking trails and tourism impact assessment in protected area: Jiuzhaigou Biosphere Reserve, China. Environmental Monitoring and Assessment, 108, 279-293, 2005.

[7] Moore, S.A. \& Polley, A., Defining indicators and standards for tourism impacts in protected areas: Cape Range National Park, Australia. Environmental Management, 39, pp. 291-300, 2007. 
[8] Gül, A., Örücü, M.K. \& Karaca, Ö., An approach for recreation suitability analysis to recreation planning in Gölcük Nature Park. Environmental Management, 37 (5), pp. 606-625, 2006.

[9] Roman, S.J., Dearden, P. \& Rollins, R., Application of zoning and "Limits of Acceptable Change" to manage snorkelling tourism. Environmental Management, 39, pp. 819-830, 2007.

[10] Schonewald-Cox, C., Buechner, M., Sauvajot, R. \& Wilcox, B.A., Crossboundary management between National Parks and surrounding lands: a review and discussion. Environmental Management, 16, pp. 273-282, 1992.

[11] Gulinck, H., Vyverman, N., Van Bouchout, K. \& Gobin, A., Landscape as framework for integrating local subsistence and ecotourism: a case study in Zimbabwe. Landscape and Urban Planning, 53, 173-182, 2001.

[12] Margules, C.R. \& Pressey, R.L., Systematic conservation planning. Nature, 405, pp. 243-253, 2000.

[13] Tischendorf, L. \& Fahrig, L., How should we measure landscape connectivity? Landscape Ecology, 15, pp. 633-641, 2000.

[14] Cerdeira, J.O., Gaston, K.J. \& Pinto, L.S., Connectivity in priority area selection for conservation. Environmental Modelling and Assessment, 10, pp. 183-192, 2005.

[15] Rothley, K.D., Finding the tradeoffs between the reserve design and representation. Environmental Management, 38, pp. 327-337, 2006.

[16] Pineda, F.D., Schmitz, M.F., de Aranzabal, I., Hernández, S., Aguilera \& P., Bautista, C., Landscape ecological connectivity between a protected area network and surrounding lands. Junta de Andalucía: Sevilla, 2008. In press.

[17] Bell, S., Design for outdoor recreation. Spon Press: London, pp. 217, 2001.

[18] Roovers, P., Hermy, M. \& Gulinck, H., Visitor profile, perceptions and expectations in forests from a gradient of increasing urbanization in central Belgium. Landscape and Urban Planning, 59, pp. 129-145, 2002.

[19] Schmitz, M.F., Fernández-Sañudo, P., De Aranzabal. I. \& Pineda, F.D., Visitors' valuation of natural and cultural landscapes: space-preferences coincidence analysis. In: Sustainable Tourism, eds. F.D. Pineda \& C.A. Brebbia, WIT Press: Southampton, Boston, pp. 307-317, 2004.

[20] Schmitz M.F., Ruiz-Labourdette, D., Sañudo, P.F., Montes, C. \& Pineda, F.D., Participation of visitors in the management design of protected natural areas. In: Sustainable Tourism II, eds. F.D. Pineda \& C.A. Brebbia, WIT Press: Southampton, Boston, pp. 139-148, 2006.

[21] Schmitz, M.F., De Aranzabal, I. \& Pineda, F.D., Spatial analysis of visitor preferences in the outdoor recreational niche of Mediterranean cultural landscapes. Environmental Conservation, 34, pp. 300-312, 2007.

[22] Lacitignola, D., Petrosillo, I., Cataldi, M. \& Zurlini, G., Modelling socioecological tourism-based systems for sustainability. Ecological Modelling, 206, pp. 191-204, 2007.

[23] Petrosillo, I., Zurlini, G., Corlianò, M.E., Zaccarelli, N. \& Dadazo, M., Tourist perception of recreational environment and management in a 
marine protected area. Landscape and Urban Planning, 79, pp. 29-37, 2007.

[24] Daily, G.C., Management objectives for protection of ecosystem services. Environmental Science and Policy, 3, pp. 333-339, 2000.

[25] Soulé, M.E., Conservation: tactics for a constant crisis. Science, 253, pp. 744-750, 1991.

[26] Martin, S.R., McCool, S.F. \& Lucas, R.C., Wilderness campsite impacts: do managers and visitors see them the same? Environmental Management, 13, pp. 623-629, 1989.

[27] Farrell, A.E., VanDeveer, S. \& Jäger, J., Environmental assessments: four under-appreciated elements of design. Global Environmental Change, 11, pp. 311-333, 2001.

[28] Dasdemir, I., Improving Operational Planning and Management of National Parks in Turkey: A Case Study. Environmental Management, 35(3), pp. 247-257, 2005.

[29] Buisson, E. \& Dutoit, T., Creation of the natural reserve of La Crau: Implications for the creation and management of protected areas. Journal of Environmental Management, 80(4), pp. 318-326, 2006.

[30] Cihar, M. \& Stankova, J., Attitudes of stakeholders towards the Podyji/Thaya River Basin National Park in the Czech Republic. Journal of Environmental Management, 81, pp. 273-285, 2006.

[31] Nebbia, A.J. \& Zalba, S.M., Designing nature reserves: traditional criteria may act as misleading indicators of quality. Biodiversity and Conservation 16, pp. 223-233, 2007.

[32] Steiner, F., McSherry, L. \& Cohen, J., Land suitability analysis for the upper Gila River watershed. Landscape and Urban Planning, 50, pp. 199 214, 2000. 